\title{
An Investigation Into the Frequency of Use of Traditional and Complementary Medicine in Patients Presenting to the Dermatology Clinic: A Survey Study
}

\section{(1) Ebru Karagün}

Duzce University Faculty of Medicine, Department of Dermatology, Duzce, Turkey

\section{ABSTRACT}

Background: Although interest in traditional and complementary medicine (TCM) methods has grown, patients are still reluctant to inform physicians that they employ these. Reasons for the increase in the frequency of TCM methods include interventional procedures being performed less or not at all, and the perception that topical treatment is harmless. The great majority of people who use TCM methods acquire the relevant information from the internet and those around them. Physicians therefore need to be aware of such trends and to protect patients against incorrect use by informing them accordingly. The purpose of this study was to investigate the frequency of the use of TCM methods among patients presenting to the dermatology clinic.

Materials and Methods: Patients presenting to the dermatology clinic between June 2018-April 2019, aged over 15, and with symptoms persisting for longer than six weeks was included in the study. Disoriented or uncooperative patients were excluded. Patients agreeing to participate read and signed informed consent forms, after which a question and answer type questionnaire was administered to collect data about TCM applications.

Results: Six hundred fifty-one patients, $56.9 \%$ of whom were women, took part, and $13.3 \%$ had used TCM. Herbal remedies were the most frequently employed method at $67.8 \%$, followed by cupping at $16 \%$, leeches at $13.7 \%$, and moxibustion at $2.2 \%$. Frequency of use was $48.2 \%$ among women and $51.8 \%$ among men, while in terms of age the frequency was highest in the $45-55$ age range, and in terms of education use was highest among university graduates.

Conclusion: Patients attending for examination should be given information to protect against misuse of TCM methods by inquiring into their attitudes toward them, especially those failing to benefit from the treatment administered or with recurring symptoms. Physicians must be aware of such tendencies on the part of patients and must inform patients about these methods when necessary.

Keywords: Traditional treatment, Complementary treatment, Dermatology

\section{Introduction}

Modern/conventional medicine was born from Hippocrates' (460356 BC) idea of investigating the cause and effect relationship during diagnosis, treatment, and prognosis through accumulated experiences. Freed from being a combination of religious faith, magic, and methods based on empirical treatment applied by priest-physicians, the foundations were laid for it to become a true science [1]. When assistant methods are applied in addition to modern medicine, this is known as 'complementary medicine,' while the use of such techniques instead of modern medicine is known as 'alternative medicine.' Based on World Health Organization definitions, the term 'traditional and complementary medicine (TCM)' decision that from there is no alternative to 
medicine, only to treatment could be an alternative [2]. TCM refers to the totality of skills and practices, explicable or otherwise, based on theories, beliefs, and experiences specific to different cultures in the preservation of health in addition to protecting against, diagnosing, and healing or treating physical and mental diseases [3]. Fifteen forms of TCM are currently approved by the Turkish Ministry of Health - phytotherapy, mesotherapy, larval therapy, prolotherapy, cupping, music therapy, hypnotherapy, homeopathy, leech therapy, ozone therapy, osteopathy, reflexology, acupuncture, apitherapy, and chiropractic [2]. Diseases have been present throughout human history, and there has been a constant search for treatments. The search for a solution outside evidence-based medicine on the part of the patient or relative, the knowledge that the disease in question may persist for a lifetime, recurrence of symptoms after treatment, and the belief that natural compounds have no side-effects all encourage the use of TCM [4]. Reasons for use vary among countries depending on their level of development. In developing countries, TCM is used to meet the basic health needs of communities, while in developed countries it is more used in diseases to which conventional medicine fails to find a solution [5]. Previous studies have investigated the use of TCM among patients presenting to dermatology clinics in countries with very different sociocultural characteristics, such as Singapore [6], the USA [7], the United Kingdom [8], Taiwan [9], Saudi Arabia [10], and Iran [11]. The common finding of these studies is that TCM is commonly employed among patients presenting to dermatology clinics, that patients are reluctant to report this, and that dermatologists therefore need to raise their awareness on the subject of TCM. However, the number of studies from Turkey investigating the frequency of use of TCM in the field of dermatology, the methods employed, and the frequency of their side-effects and effectiveness, is insufficient.

The purpose of this study was to investigate the use of TCM among patients with dermatological symptoms persisting for longer than six weeks presenting to a dermatology clinic in Turkey.

\section{Materials and Methods}

Patients presenting to the dermatology clinic between June 2018 and April 2019, aged over 15, and with symptoms persisting for longer than six weeks, and patients attending routine clinical follow-ups were included in the study. Disoriented or uncooperative patients were excluded. All patients meeting the inclusion/exclusion criteria were invited to take part. Patients agreeing to participate read and signed informed consent forms, after which a question and answer type structured questionnaire (Appendix 1) was administered to collect data about TCM applications.

Approval for the study was granted by the Duzce University Ethical Committee (no: 2019/109).

\section{Statistical Analysis}

Statistical analysis was performed on Statistical Package for the Social Sciences Software (Windows 20.0; SPSS Inc., IL, USA). Descriptive statistics were calculated as frequency and percentage for categorical variables.

\section{Results}

Demographic data for the patients in the study are shown in Table 1, and distributions of TCM use among patients using TCM are shown by age, sex, and education level in Table 2 .

In Table 3, TCM was employed by $13.3 \%$ of the patients in the study. The most popular TCM method, at $67.8 \%$, was herbal products. Cupping was used by $16 \%$ of patients, leech therapy by $13.7 \%$, and moxibustion by $2.2 \%$.

Table 1. Demographic data

\begin{tabular}{|l|l|l|}
\hline \multirow{4}{*}{ Sex } & Male & 280 \\
\cline { 2 - 3 } Age & Female & 371 \\
\hline \multirow{5}{*}{ Education } & $15-25$ & 146 \\
\cline { 2 - 3 } & $25-35$ & 160 \\
\cline { 2 - 3 } & $35-45$ & 142 \\
\cline { 2 - 3 } & $45-55$ & 128 \\
\hline \multirow{5}{*}{} & 55 and over & 75 \\
\hline & Illiterate & 22 \\
\cline { 2 - 3 } & Literate & 31 \\
\cline { 2 - 3 } & Elementary school & 113 \\
\cline { 2 - 3 } & Middle school & 63 \\
\hline & High school & 210 \\
\hline & University & 212 \\
\hline
\end{tabular}

Table 2. Rates of traditional-complementary medicine use by sex, age and education level

\begin{tabular}{|l|l|l|}
\multirow{4}{*}{ Sex } & Female & $42(48.2 \%)$ \\
\cline { 2 - 3 } Age & Male & $45(51.8 \%)$ \\
\hline \multirow{4}{*}{ Education } & 25-35 years & $12(8.2 \%)$ \\
\cline { 2 - 3 } & 35-45 years & $20(12.5 \%)$ \\
\hline \multirow{5}{*}{ 45-55 years } & $14(9.8 \%)$ \\
\hline & 55 or over & $28(31.1 \%)$ \\
\hline & Illiterate & $13(14.9 \%)$ \\
\cline { 2 - 3 } & Literate & $3(13.6 \%)$ \\
\cline { 2 - 3 } & Elementary school & $2(6.4 \%)$ \\
\cline { 2 - 3 } & Middle school & $16(14.1 \%)$ \\
\cline { 2 - 3 } & High school & $18(8.5 \%)$ \\
\cline { 2 - 3 } & University & $38(17.9 \%)$ \\
\hline
\end{tabular}


Table 3. Traditional-complementary medicine questionnaire results

\begin{tabular}{|c|c|c|}
\hline \multirow{2}{*}{ TCM } & Using & $87(13.3 \%)$ \\
\hline & Thinking of using & 27 \\
\hline \multirow{6}{*}{ Diagnosis } & Erythematous-squamous diseases & 27 \\
\hline & Chronic pruritus- chronic urticaria & 7 \\
\hline & Zona zoster-related pain & 5 \\
\hline & Chronic eczema & 36 \\
\hline & Stasis ulcer-chronic wounds & 4 \\
\hline & Other & 8 \\
\hline \multirow{3}{*}{ Duration of disease } & $<5$ years & 449 \\
\hline & $5-10$ years & 124 \\
\hline & $>10$ years & 78 \\
\hline \multirow[t]{2}{*}{ Additional chronic disease } & Yes & 205 \\
\hline & No & 446 \\
\hline \multirow{7}{*}{ TCM method(s) used } & Herbal products (as ointment) & 59 \\
\hline & Herbal products (for eating or drinking) & $-\cdots--$ \\
\hline & Acupuncture & ---- \\
\hline & Cupping & 14 \\
\hline & Leech therapy & 12 \\
\hline & Moxibustion & 2 \\
\hline & Other & $-\cdots--$ \\
\hline \multirow{3}{*}{ Aims behind TCM use } & Support & 85 \\
\hline & Treatment & 2 \\
\hline & Protection against attacks & --- \\
\hline \multirow{3}{*}{ Benefit obtained from TCM methods } & Yes & 2 \\
\hline & No & 85 \\
\hline & Worsening of symptoms & 12 \\
\hline \multirow{2}{*}{ Prior receipt of information about TCM } & Yes & 72 \\
\hline & No & 15 \\
\hline \multirow[t]{2}{*}{ Did the information you obtained come from the internet? } & Yes & 40 \\
\hline & No & 15 \\
\hline \multirow[t]{2}{*}{ Did you have your TCM method applied in a hospital setting? } & Yes & 20 \\
\hline & No & 67 \\
\hline \multirow[t]{2}{*}{ Did any side-effects arise from the TCM method? } & Yes & 14 \\
\hline & No & 63 \\
\hline If you used TCM, would you use it again? & \multicolumn{2}{|c|}{ Twenty-four out of 87 patients stated they might use it again } \\
\hline TCM: Traditional-complementary medicine & & \\
\hline
\end{tabular}

Three of the seven patients with psoriasis used leech therapy, and four used cupping.

The seven patients with chronic pruritus and chronic urticaria applied cupping.

Two of the patients with zona zoster-related post-herpetic neuralgia employed cupping, one employed leech therapy, and two used moxibustion.
Two patients with acne rosacea employed leech therapy, but reported an increase in their symptoms. Three out of four patients with androgenic alopecia used leech therapy, and one employed cupping.

Three patients with venous ulcer employed leech therapy, with healing accelerating in one of these, and other reporting partial improvement. Fifty-nine patients with existing diagnoses of chronic 
eczema and psoriasis reported employing creams made from various herbal compounds.

In terms of side-effects, cupping-related scarring was determined in one patient, worsening of lesions after cupping in three patients, allergic contact dermatitis associated with creams applied in two patients, cheloid in leech bite points in one patient, and allergic reaction after leech therapy in three patients in Table 3.

\section{Discussion}

As in the rest of the world, procedures described as TCM began being increasingly employed in Turkey after the 1990s. However, $60-80 \%$ of patients using TCM methods are reported to conceal this from their physicians [12]. Reported TCM use rates among patients presenting to dermatology clinics are $25.7 \%$ in Singapore [6], $45 \%$ in the United Kingdom [8], 41\% in Taiwan [9], 40\% in Saudi Arabia [10], and $31.3 \%$ in Ireland [11].

In their study of 1.610 patients from eastern Turkey, Bilgili et al. [13] determined that $43.7 \%$ used at least one TCM method, particularly henna, cologne, prayer, and herbal remedies. Can et al. [14] reported TCM use among $26.1 \%$ of pediatric patients, most commonly herbal remedies, and that the father being a university graduate increased the use rate. In a study of 217 patients, Sivamani et al. [15] found that $13.4 \%$ used TCM, the most common method again being herbal remedies. A review of 58 studies from 19 countries reported that TCM use rates ranged between $8 \%$ and $48.5 \%$, and concluded that homeopathy was more common in Germany, the United Kingdom, and Canada, while the use of herbal remedies was more frequent in Germany, Turkey and Brazil [16].

The TCM use rate in the present study was $13.3 \%$, the most commonly employed method being herbal remedies at $67.8 \%$. The highest rate of use was among university graduates at $17.9 \%(n=38)$. No patients in this study used acupuncture for dermatological diseases.

The second most commonly applied TCM method after herbal remedies was cupping, at $16 \%$. Patients with psoriasis, chronic pruritus, chronic urticaria, post-herpetic neuralgia, and androgenic alopecia had cupping performed. Cupping is a traditional therapy that has been performed for thousands of years across the world [17]. There are two forms of cupping - dry and wet. It is defined as eliminating 'stagnant blood' from the body [5]. Studies have investigated its use in various medical conditions, including dermatological applications. Despite the absence of high-quality clinical studies evaluating the effectiveness of cupping therapy, it is widely employed worldwide [17]. Several studies have discussed inappropriate applications resulting in various complications [18]. A review of 12 randomized controlled studies involving 842 patients with urticia reported that wet cupping might be capable of enhancing the efficacy of antihistaminic therapy. However, that review also reported that the need for attention in the results of studies regarding cupping since they might be poor quality [19]. A meta-analysis of studies involving the application of cupping in patients with psoriasis concluded that it was not effective in treating the [20]. Paradoxically, there are numerous cases in the literature of the Koebner phenomenon developing in association with cupping [21,22]. Tian et al. [23] found that wet cupping exhibited its effect by reducing substance $P$ levels in patients with postherpetic neuralgia. Another study also reported that cupping was effective in shingles-related post-herpetic neuralgia [24]. The most commonly encountered side-effects of cupping include anemia due to excessive bleeding $[25,26]$ and herpes virus infection [27]. Later changes include scarring in the incision site and hyperpigmentation [28]. Histories revealed exacerbation of lesions occurred following cupping in patients diagnosed with psoriasis in this study, partial improvement in one patient with chronic pruritus and post-herpetic neuralgia, and to no therapeutic effectiveness in other patients taking part.

Leech therapy was employed by $13.7 \%$ of the patients in this study. The treatment of medical problems using medical leeches is known as hirudotherapy. Leeches feed on the blood of the organism to which they attach themselves. Anesthetic substances in leech secretions reduce pain, while their anticoagulant properties prevent clotting. The effects of leech therapy are thought to be due to the secretions containing hirudin, hyaluronidase, kaline, destabilase, aspirase, eglin, bdellin, dekorsin, guamerin, piguamerin, gelin, gamma-glutamyl transpeptidase, platelet-activating factor antagonist, ornithine-rich plasma, and other active biomolecules [29]. The US Food and Drug Administration approved the use of medical leeches in the healing of graft tissue and problems associated with venous congestion in 2004 [30]. Cases have been reported of successful use of leech application in healing chronic wounds [30,31] and venous congestion [32]. In an analysis of case reports and case series collected from 67 different article, Whitaker et al. [33] reported that leech application assisted flap rescue in 216 patients undergoing flap surgery. In addition to the proven efficacy of leech therapy, Aktaş and Hamidi [34] reported a different case, of a patient treated on an outpatient basis for warts recalcitrant to treatment persisting for seven years. Those authors reported that shrinkage occurred followed leech therapy applied by the patient. Two patients with rosea in this study underwent leech therapy, but reported a worsening in their symptoms. Three patients with venous ulcers had leech therapy performed, with one reporting accelerated healing and another partial improvement. Patients with existing psoriasis reported no effectiveness of leech therapy, and one reported increased pruritus as a side-effect. The most commonly reported side-effect of leech application is infection, at a rate of $21.8 \%$. Infections arise from the leech's microbiota 
[33]. Bauters et al. [35] determined an infection rate of $27.5 \%$ and recommended the prophylactic use of levofloxacin. One rare sideeffect is pseudolymphoma $[36,37,38]$. Another side-effect that may be seen is allergic reaction [39]. Hemoglobin should be monitored due to continuous blood loss for several hours during and after leech therapy, and transfusion must be performed if necessary [33]. Three patients presented to our clinic due to development of allergy (Figure 1) following leech therapy. One patient also presented due to cheloid after leech therapy. A patient with existing venous congestion and chronic venous ulcer reported benefitting after leech application. Leech applications can be employed for wound healing due to their prophylactic and palliative effects. However, standard procedures and scientific parameters need to be developed if the effectiveness of leech application is to be proved in a rational manner.

Herbal remedies were the most commonly used TCM method in this study. These have been used in the treatment of dermatological diseases for hundreds of years [40]. The use of natural herbal compounds has become increasingly popular in recent years [41]. Recent research from the USA has determined use of a herbal product among $20-60 \%$ of adolescents and in $70 \%$ of individuals between 30 and 40 . Men frequently use these for therapeutic purposes, while women more often employ them for cosmetic reasons [41]. In a study from Iran, Dastgheib et al. [11] reported that $31.3 \%$ ( $n=188$ ) of 600 patients used TCM. The great majority of these patients, $89.9 \%$, favored herbal products. The majority of patients using herbal remedies were also in the eczema group. According to the World Health Organization, some 35,000-70,000 plants worldwide are used for therapeutic purposes, of which only 5.000 have been subjected to medical analysis [42]. These products, generally inaccurately described as herbal medicines, are

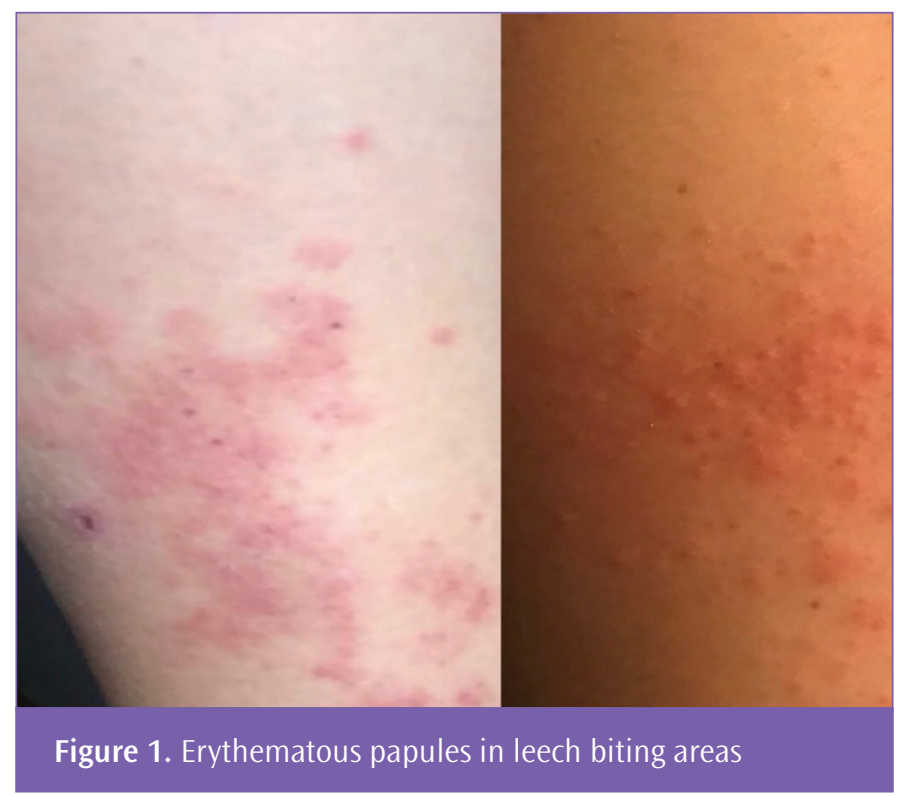

propagated by physicians and non-physicians based on reports with no supporting scientific evidence, and are sold in places where they are easily accessible to all. Although patients are reluctant to admit to using these products, they employ them in an uncontrolled manner out of the belief that 'natural products are harmless.' Worsening of lesions was observed in a patient receiving biological therapy and under follow-up by ourselves. When asked about this, the patient stated that she had purchased a product containing seaweed online, had rubbed it on her body and left it there for six $\mathrm{h}$, and that the symptoms had subsequently worsened within one week.

\section{Study Limitation}

The number of patients is limited in terms of survey study.

\section{Conclusion}

TCM enjoys a wider range of use than physicians may expect. Patients are largely advised to use TCM by non-professionals. They are also reluctant to consult physicians to obtain information about the applications they are considering using. They use the internet, the media, and friends and relatives as sources of information, for which reason TCM usage rates are rising. Patients should be asked about the use of TCM when an otherwise unexplained worsening in lesions is detected. At the same time, it should always be remembered that the TCM methods employed may interact with conventional medications.

\section{Ethics}

Ethics Committee Approval: The study was conducted in the light of the declaration of Helsinki and followed a protocol approved by Duzce University Ethical Committee (approval number: 2019/109).

Informed Consent: Patients were recruited in the study after being given informed consent.

Peer-review: Internally peer-reviewed.

Financial Disclosure: The author declared that this study received no financial support.

\section{References}

1. Şahin S. Türkiye Aile Hekimliği Dergisi 2017;21:159-162.

2. Geleneksel ve tamamlayıı tıp uygulamaları yönetmeliği. 27 Ekim 2014 tarih ve 29158 sayılı Resmi Gazete. Erișim adresi: https://www.resmigazete.gov.tr/ eskiler/2014/10/20141027-3.htm?ref=bulabul.com

3. World Health Organization. General Guidelines for Methodologies on Research and Evaluation of Traditional Medicine. Geneva: WHO Books; 2000:80

4. Somer P, Vatanoğlu-Lutz EE. Geleneksel ve Tamamlayıcı Tıp Uygulamaları Yönetmeliği'nin Hukuki ve Etik Açıdan Değerlendirilmesi. Anatolian Clin 2017;2:58-65.

5. Yüksel NA, Açıkgöz B, Yüksel C, Ayoğlu FN, Er T. Hekimlerin Geleneksel ve Tamamlayıcı Tıp Uygulamalarına Bakıș Açısı. ESTÜDAM Halk Sağlığı Dergisi 2019;4:276-286. 
6. See A, Teo B, Kwan R, Lim R, Lee J, Tang MB, Verkooijen HM. Use of complementary and alternative medicine among dermatology outpatients in Singapore. Australas J Dermatol 2011;52:7-13.

7. Landis ET, Davis SA, Feldman SR, Taylor S. Complementary and alternative medicine use in dermatology in the United States. J Altern Complement Med 2014;20:392-398.

8. Baron SE, Goodwin RG, Nicolau N, Blackford S, Goulden V. Use of complementary medicine among outpatients with dermatologic conditions within Yorkshire and South Wales, United Kingdom. J Am Acad Dermatol 2005;52:589-594.

9. Chen YF, Chang JS. Complementary and alternative medicine use among patients attending a hospital dermatology clinic in Taiwan. Int J Dermatol 2003;42:616-621.

10. A AlGhamdi KM, Khurrum H, Al-Natour SH, Alghamdi W, Mubki T, Alzolibani A, Hafez DM, AlDraibi M. Use of Complementary and Alternative Medicine Among Dermatology Outpatients: Results From a National Survey. J Cutan Med Surg 2015;19:570-579.

11. Dastgheib L, Farahangiz S, Adelpour Z, Salehi A. The Prevalence of Complementary and Alternative Medicine Use Among Dermatology Outpatients in Shiraz, Iran. J Evid Based Complementary Altern Med 2017;22:731-735.

12. Türk Tabipleri Birliği Halk Sağlığı Kolu. Available from: www.ttb.org.tr , kutuphane ' gatt_2017

13. Bilgili SG, Ozkol HU, Karadag AS, Calka O. The use of complementary and alternative medicine among dermatology outpatients in Eastern Turkey. Hum Exp Toxicol 2014;33:214-221.

14. Can B, Akan H, Demir FT, Zindanci I, Cebeci F, Turkoglu Z, Kavala M. Complementary and Alternative Therapies Used by Patients of Pediatric Dermatology Outpatient Clinics in Turkey: A Multicenter Study. Pediatr Dermatol 2017;34:72-77.

15. Sivamani RK, Morley JE, Rehal B, Armstrong AW. Comparative prevalence of complementary and alternative medicine use among outpatients in dermatology and primary care clinics. JAMA Dermatol 2014;150:1363-1365.

16. Italia S, Wolfenstetter SB, Teuner CM. Patterns of complementary and alternative medicine (CAM) use in children: a systematic review. Eur J Pediatr 2014; 173:1413-1428.

17. Lowe DT. Cupping therapy: An analysis of the effects of suction on skin and the possible influence on human health. Complement Ther Clin Pract 2017;29:162-168.

18. Abbas Zaidi SM, Jameel SS, Jafri K, Khan SA, Ahmad E. Ilaj bil hijamah (cupping therapy) in the Unani system of medicine: anecdotal practice to evidence based therapy. Acta Med Hist Adriat 2016;14:81-94.

19. Xiao XJ, Zhang LX, Shi YZ, Yao JP, Cao W, Liu Y, Zou ZH, Zhou SY, Chen ML, Li CX, Zheng QH, Li Y. Cupping therapy for patients with chronic urticaria: A systematic review and meta-analysis. J Integr Med 2020;18:303-312.

20. Zhang J, Yu Q, Peng L, Zhang F, Lin W, Guo J, Xiao M, Chen M. Cupping for psoriasis vulgaris: A protocol of systematic review and meta-analysis. Medicine (Baltimore) 2020;99:e20348.

21. Vender R, Vender R. Paradoxical, Cupping-Induced Localized Psoriasis: A Koebner Phenomenon. J Cutan Med Surg 2015;19:320-322.

22. Yu RX, Hui Y, Li CR. Köebner phenomenon induced by cupping therapy in a psoriasis patient. Dermatol Online J 2013;19:18575.
23. Tian H, Tian YJ, Wang B, Yang L, Wang YY, Yang JS. Impacts of bleeding and cupping therapy on serum $P$ substance in patients of postherpetic neuralgia. Zhongguo Zhen Jiu 2013;33:678-681.

24. Cao H, Li X, Liu J. An updated review of the efficacy of cupping therapy. PloS one 2012;7:e31793.

25. Lee HJ, Park NH, Yun HJ, Kim S, Jo DY. Cupping therapy-induced iron deficiency anemia in a healthy man. Am J Med 2008;121:5-6.

26. Kim TH, Kim KH, Choi JY, Lee MS. Adverse events related to cupping therapy in studies conducted in Korea: a systematic review. Eur J Integr Med 2014;6:434-440.

27. Jung YJ, Kim JH, Lee HJ, Bak H, Hong SP, Jeon SY, Ahn SK. A herpes simplex virus infection secondary to acupuncture and cupping. Ann Dermatol 2011;23:67-69.

28. Okumuş M. Kupa Tedavisi ve Hacamat. Ankara Med J 2016;4:370-382.

29. Yıldız S, Eriş S, Polat NY, Ürper S, Kurt Y, Kurt BB, Yıldız ÜG. Sülük Tedavisi. Integr Tıp Derg 2014;2:21-25.

30. Iqbal A, Jan A, Wajid MA, Tariq S. Management of Chronic Non-healing Wounds by Hirudotherapy. World J Plast Surg 2017;6:9-17.

31. Kim KS, Sim HS, Shin JH, Hwang JH, Lee SY. The Relationship between Explanation and Patient Compliance in Hirudotherapy. Arch Craniofac Surg 2017;18:179-185.

32. Brzezinski P, Solovan C, Chiriac A, Foia L. Positive outcome of medical leeches (hirudotherapy) for venous congestion. Malawi Med J 2015;27:38-39.

33. Whitaker IS, Oboumarzouk O, Rozen WM, Naderi N, Balasubramanian SP, Azzopardi EA, Kon M. The efficacy of medicinal leeches in plastic and reconstructive surgery: a systematic review of 277 reported clinical cases. Microsurgery 2012;32:240-250.

34. Aktaş H, Hamidi AA. A longstanding giant plantar wart cleared with medicinal leech application in an immunosuppressive patient. Clin Exp Dermatol 2020;45:463-464.

35. Bauters T, Buyle F, Blot S, Robays H, Vogelaers D, Van Landuyt K, Vanhove W, Claeys $\mathrm{G}$. Prophylactic use of levofl oxacin during medicinal leech therapy. Int J Clin Pharm 2014;36:995-999.

36. Tupikowska M, Woźniak Z, Wojciechowska-Zdrojowy M, Maj J, JankowskaKonsur A. Hirudotherapy - a rare cause of pseudolymphoma. Postepy Dermatol Alergol 2018;35:225-226.

37. Temiz SA, Özer İ, Ataseven A, Dursun R, FındıkS. Cutaneous Pseudolymphoma Due to Hirudotherapy. Turkiye Parazitol Derg 2019;43:50-52.

38. Khelifa E, Kaya G, Laffitte E. Cutaneous pseudolymphomas after leech therapy. J Dermatol 2013;40:674-675.

39. Pietrzak A, Kanitakis J, Tomasiewicz K, Wawrzycki B, Kozłowska-Łój J, Dybiec E, Chodorowska G. Cutaneous complications of improper leech application. Ann Agric Environ Med 2012;19:790-792.

40. Hoffmann J, Gendrisch F, Schempp CM, Wölfle U. New Herbal Biomedicines for the Topical Treatment of Dermatological Disorders. Biomedicines 2020;8:27

41. Mortimer S, Reeder M. Botanicals in dermatology: essential oils, botanical allergens, and current regulatory practices. Dermatitis 2016;27:317-324.

42. Ünal M, Dağdeviren HN. Geleneksel ve Tamamlayıcı Tıp Yöntemleri. Euras ] Fam Med 2019;8:1-9. 
Appendix 1. Traditional and complementary medicine method use questionnaire for patients with chronic dermatological diseases

Age:

Sex:

$\square$ Male $\square$ Female

Education:

$\square$ Illiterate $\square$ Literate $\square$ Elementary school $\square$ Middle school $\square$ High school University and above

Diagnosis:

Duration of disease:

5 years $\square 5-10$ years $\square>10$ years

Additional chronic disease:

$\square$ Yes $\square$ No

Use of TCM:

$\square$ Yes $\square$ No

Which TCM methods do you use?:

$\square$ Herbal products (as ointment) $\square$ Aromatherapy (oils) $\square$ Acupuncture $\quad \square$ Cupping $\square$ Leech therapy $\square$ Moxibustion $\quad \square$ Other

Reason for use of TCM methods:

Relief $\square$ Support $\square$ Treatment $\square$ Protection against attacks

Symptoms requiring use of TCM methods:

Itching $\square$ Rash $\square$ Pain $\square$ Dissatisfaction with external appearance

Benefit obtained from TCM methods?

$\square$ Yes $\square$ No

If benefit was achieved, which symptoms improved?

Itching $\square$ Rash $\square$ Pain Dissatisfaction with external appearance

Did you receive treatment alongside TCM?

$\square$ Yes $\square$ No

Receipt of information about the TCM method concerned prior to application?

$\square$ Yes $\square$ No

Was information requested from a physician?

$\square$ Yes $\square$ No

Did you obtain information from the internet?

$\square$ Yes $\square$ No

Did the TCM method cause any side-effects?

Yes, if so which

No

If you employed TCM, would you use it again?

$\square$ Yes $\square$ No

TCM: Traditional-complementary medicine

82 